\title{
THE CRITERION FOR FEATURE INFORMATIVENESS ESTIMATION IN MULTI ROBOT TEAMS CONTROL
}

Humeniuk M. O. - PhD, Associate Professor of Department of Unmanned Aircraft Systems Applications, Zhytomyr Military Institute named after S. P. Koroliov, Zhytomyr, Ukraine.

Sashchuk I. M. - PhD, Senior Research Fellow, Deputy Chief of the Institute for Academic and Scientific Work, Zhytomyr Military Institute named after S. P. Koroliov, Zhytomyr, Ukraine.

Zhuravsky Yu. V. - Dr.Sc., Senior Research Fellow, Leading Researcher at the Scientific Center, Zhytomyr Military Institute named after S. P. Koroliov, Zhytomyr, Ukraine.

\section{ABSTRACT}

Context. The task of automation of feature set informativeness estimation process in multi robot teams control is solved. The object of the research is the process of multi robot teams control. The subject of the research is the criterion of feature set informativeness estimation.

Objective. The research objective is to develop the criterion for feature set informativeness estimation in multi robot teams control.

Method. The criterion for feature set informativeness estimation is proposed. The developed criterion is based on the idea that feature set informativeness is computed according to values of the prior probabilities of finding features in the descriptions of the environment states. The use of the proposed criterion allows to efficiently solve the problem of feature set informativeness estimation, leading to effective solution of the multi robots control task. The developed criterion is based on the maximizing mutual information criterion and can be applicable when measurements are interdepended and environment has a variable number of states. The criterion doesn't require to construct models based on the estimated feature combinations, in such a way considerably reducing time and computing costs for multi robot teams control. Application of the proposed criterion for feature set informativeness estimation allows to make a decision how much a new observation will increase the certainty of the robots' beliefs about the environment state which is observed.

Results. The software which implements the proposed criterion for feature set informativeness estimation and allows to manage multi robot teams has been developed.

Conclusions. The conducted experiments have confirmed operability of the proposed criterion for feature set informativeness estimation and allow to recommend it for multi robot teams control in practice. The prospects for further researches may include the modification of the known multi robot teams control methods and the development of new ones based on the proposed criterion for feature set informativeness estimation.

KEYWORDS: multi robot teams control, mutual information, informativeness criterion, feature set informativeness.

\section{NOMENCLATURE}

$p\left(L_{i}\right)$ is a prior probability of the environment state $L_{i}$;

$p\left(x_{k j}\right)$ is the prior probability of the situation when a feature $k$ has value $j$;

$p\left(x_{k j} / L_{i}\right)$ is a probability of the situation when a feature $k$ has value $j$ on condition that output parameter has value $L_{i}$;

$N$ is a number of possible environment states $i=\overline{1, N}$;

$p\left(L_{i} / x_{k j}\right)$ is a probability of the situation when the environment state has value $L_{i}$ on condition that feature has value $x_{k j}$;

$J$ is a number of feature values $j=\overline{1, J}$;

$n$ is a number of features $k=\overline{1, n}$;

$a_{C}$ is a possible robots action;

$D$ is a number of possible robots actions $c=\overline{1, D}$;

$H_{0}(L)$ is a prior entropy of the environment state;

$I_{k}(L)$ is a informativeness of the $k$-th feature;
$I(L)$ is a informativeness of the feature set;

$E(L)$ is a relative informativeness of the feature set;

$I_{\beta}(L)$ is a informativeness of the $\beta$ feature;

$\left(I_{\beta}(L)\right)_{\max }$ is a maximum possible informativeness of the $\beta$ feature;

$\gamma_{k \beta}$ is a coefficient characterizing the statistical connection between $k$ and $\beta$-th features;

$p_{e}(L)$ is a classification error of the environment state;

$p_{e}^{r}$ is a required classification error of the environment state;

$M_{j}\left(x_{2 q}\right), M_{\phi}\left(x_{1 J}\right)$ are the frequencies of the values of the features;

$W$ is a sum of all measured frequencies of the consistent occurrence of the feature values;

$\left\lfloor M_{j \phi}^{0}\right\rfloor$ are hypothetical frequencies;

$H_{r}(L)$ is the required entropy of the environment state;

$I_{r}(L)$ is the required amount of mutual information of the environment state; 
$I^{*}(L)$ is an amount of mutual information which multi robot teams receive from action;

$I_{r}^{*}$ and $I^{*}$ are amounts of information that can be determined based on the value of the required probability of the clasification error.

\section{INTRODUCTION}

Multi robot teams that intelligently gather information have the potential to transform industries as diverse as agriculture, space exploration, mining, environmental monitoring, search and rescue, and construction. Despite large amounts of research effort on active perception problems, there still remain significant challenges.

The ultimate goal of an active perception problem is to estimate some unknown quantity of interest. Most modern perception approaches are probabilistic [1]; instead of forming a single concrete guess of what something is, they determine a probability distribution over possible values that it could be. Consequently, the goal of an active perception strategy is to reduce the uncertainty of the probabilistic estimate as quickly as possible. To formally define this goal of "uncertainty reduction," a lot of modern approaches use information theory. According to them the robots are controlled to seek informative observations by moving along the gradient of mutual information at each time step. Mutual information is a quantity from information theory that predicts how much a new observation will increase the certainty of the robots' beliefs about the environment state. Thus by moving along the mutual information gradient, the robots maximally increase the informativeness of their next observation.

To control this complex process we have to use feature set informativeness estimation methods that allows us to make a decision how much a new observation will increase the certainty of the robots' beliefs about the environment state.

Feature set informativeness estimation methods generally use classification error obtained by the model which was constructed using estimated data set as criterion of feature set informativeness estimation [2, 3]. Such approach needs significant computational and time costs of resources, because it is connected with computationally complex procedure of model synthesis which should be performed for every estimated feature set $[2,3]$.

Informational criteria $[2,4]$ don't require to perform computationally complex procedure of mathematical model synthesis for estimation of feature set informativeness. However, in the known approaches of multi robot teams control, such criteria suppose that features of initial data sample are independent. Therefore it is difficult to use such criteria in practice and it is unsuitable for situations when features in initial samples are interdependent.

Also, however there is a binding relationship between mutual information and classification error there is no functional relationship between these values. This does not allow us to make precise assessment of the classifica-

(C) Humeniuk M. O., Sashchuk I. M., Zhuravsky Yu. V., 2018 DOI 10.15588/1607-3274-2018-4-9 tion error in the known approaches of multi robot teams control.

The described shortcomings cause actuality of the development of the criterion for feature set informativeness estimation, which is free from these drawbacks.

The research objective is to develop the criterion for feature set informativeness estimation which enables to estimate the classification error in the task of multi robot teams control.

\section{PROBLEM STATEMENT}

Suppose we have prior probabilities $p\left(x_{k j} / L_{i}\right)$ and $p\left(L_{i}\right)$ for environment states $L=\left\{L_{1}, L_{2}, \ldots, L_{N}\right\}$ and feature set $x=\left\{x_{1}, x_{2}, \ldots, x_{n}\right\}$. Every feature $x_{k}$ is characterized by values of attributes $x_{k}=\left\{x_{k 1}, x_{k 2}, \ldots, x_{k J}\right\}$. Given a set of possible robots actions $A=\left\{a_{1}, a_{2}, \ldots, a_{D}\right\}$. Then the problem of multi robot teams control strategy can be ideally stated [1] as driving the team to obtain measurements which lead to maximize the mutual information $I^{*}(L)=\max _{a \in A} I(L)$.

\section{REVIEW OF THE LITERATURE}

Bayesian approaches for estimation have a rich history in robotics, and mutual information has recently emerged as a powerful tool for controlling robots to improve the quality of the Bayesian estimation, particularly in multi robot systems. As an early example, in $[5,6]$ was proposed controlling multiple robot platforms so as to increase the mutual information between the robots sensors and the position of a target in tracking applications. In [7] was used a similar method for exploring and mapping uncertain environments. The problem of planning paths through an environment to optimize mutual information was investigated in [8-10].

In [11] was used mutual information for control with highly non Gaussian belief states, achieving scalability by using a pairwise approximation to mutual information. In [12] was used the identical gradient of mutual information to drive a network of robots for general environment state estimation tasks. In [13] was developed a consensus algorithm to achieve decentralization and a sampling strategy to reduce complexity.

Information theoretic costs metrics also have been used to manage sensors [14], and led to algorithms to control sensor networks for information gathering over an area by parameterizing the motion of collectives of vehicles [15]. The optimal probing control law to minimize Shannon entropy for the dual control problem was shown to be the input that maximizes mutual information [16]. A property relating probability distributions, the alphadivergence, was computed for particle filters and applied to manage sensors with binary measurements, though scalability in sensor network size was not addressed, and Shannon entropy was only found in the limit of the presented equations [17]. Probability-of-detection was computed using both grid cell and particle filter estimators, 
and experimentally demonstrated [18]. An approximate method was used to estimate the expected entropy for particle filters over a finite horizon [19]. Gaussian particle filtering was used with a mutual information objective function, though the technique approximates the posterior probability distribution as Gaussian at every update [20]. The version of mutual information approximation techniques was presented in [21].

For planning approaches that seek to maximize mutual information, in [22] derived approximation guarantees for greedy maximizations of mutual information and other submodular set functions. These results were applied to mobile robot environmental monitoring problems in [23, 24]. These guarantees only hold in offline settings where teams do not update their actions based on measurements they receive. In [25] was developed a sampling based strategy for maximizing a variety of information metrics with asymptotic optimality guarantees. However, they assume that information is additive across multiple measurements (i.e., measurements are independent). This assumption limits cooperation in multi-robot settings [1] and can lead to overcondence when considering multiple measurements of the same quantity.

Information-theoretic objectives have also been used for planning and control in robotics for related information rich tasks involving uncertainty such as inspection [26], environment modeling [27], extrinsic calibration of LIDAR sensors [28], visual servoing [29], and active object modeling [30]. They have also been used for applications outside of active perception. For example, Kretzschmar and Stachniss [31] use mutual information as a criterion for storing a minimal number of laser scans toward map reconstruction.

It is necessary to admit that classification methods generally use classification error obtained by the model which was constructed using estimated data set as criterion of statistic effectiveness estimation [2, 3]. But such approach needs significant computational and time costs of resources, because it is connected with computationally complex procedure of model synthesis which should be performed for every estimated feature set [2].

Although there is a binding relationship between mutual information and prognostication or classification error there is no functional relationship between these values. This does not allow to make reliable assessment of the classification error [32] and to estimate the ratio of incorrectly recognized measurements to the total number of measurements for multi robot teams.

It means that for planning approaches to multi robot teams control which seek to maximize mutual information the increasing of the mutual information is not the same as decreasing the ratio of incorrectly recognized measurements to the total number of measurements.

Thus disadvantages of the known criteria for feature set informativeness estimation in robotics cause actuality of the development of criterion which should be free from the discovered drawbacks.
The described shortcomings cause actuality of the development of the criterion for feature set informativeness estimation, which is free from these drawbacks.

\section{MATERIALS AND METHODS}

The entropy of the environment state $L$ on condition that output parameter $x_{k}$ has value $x_{k j}$ can be defined as:

$$
H\left(L / x_{k j}\right)=-\sum_{i=1}^{N} p\left(L_{i} / x_{k j}\right) \log _{N} p\left(L_{i} / x_{k j}\right) .
$$

Use Bayes' Rule:

$$
\begin{gathered}
H\left(L / x_{k j}\right)=-\frac{1}{p\left(x_{k j}\right)} \sum_{i=1}^{N} p\left(L_{i}\right) p\left(x_{k j} / L_{i}\right) \log _{N} \frac{p\left(L_{i}\right) p\left(x_{k j} / L_{i}\right)}{\sum_{i=1}^{N} p\left(L_{i}\right) p\left(x_{k j} / L_{i}\right)}= \\
=-\frac{1}{p\left(x_{k j}\right)}\left(\begin{array}{l}
\sum_{i=1}^{N} p\left(L_{i}\right) p\left(x_{k j} / L_{i}\right) \log _{N} p\left(L_{i}\right) p\left(x_{k j} / L_{i}\right)- \\
\left.-\sum_{i=1}^{N} p\left(L_{i}\right) p\left(x_{k j} / L_{i}\right) \log _{N} \sum_{i=1}^{N} p\left(L_{i}\right) p\left(x_{k j} / L_{i}\right)\right)
\end{array}\right.
\end{gathered}
$$

To obtain an entropy solution, we find the sum of values $H\left(L / x_{k j}\right)$ for all values with weights, proportional to the probability of occurrence of each values $p\left(x_{k j}\right)$. Then

$$
\begin{aligned}
& H\left(L / x_{k}\right)=-\sum_{j=1}^{J} p\left(x_{k j}\right) H\left(L / x_{k j}\right)=-\sum_{j=1}^{J} \sum_{i=1}^{N} p\left(L_{i}, x_{k j}\right) \times \\
& \times \log _{N} p\left(L_{i}, x_{k j}\right)+\sum_{j=1}^{J} \sum_{i=1}^{N} p\left(L_{i}, x_{k j}\right) \sum_{i=1}^{N} \log _{N} p\left(L_{i}, x_{k j}\right) .
\end{aligned}
$$

The value of the prior entropy of the solution will be found by expression $H_{0}(L)=-\sum_{i=1}^{N} p\left(L_{i}\right) \log _{N} p\left(L_{i}\right)$.

The mutual information of the environment state on condition that measurements are independent is defined as $I(L)=\sum_{k=1}^{n} I_{k}(L)$

However, to estimate the informativeness of a group of statistically related features using the Shannon measure is rather difficult. Therefore it is difficult to estimate mutual information for situations when measurements are interdependent.

To solve this problem we use method which was defined in [33]. According to this method informativeness for situations when features are interdependent can be estimated as

$$
I(L)=\sum_{k=1}^{n} I_{k}(L)\left[1-\sum_{\beta=0}^{k-1} \gamma_{k \beta} \frac{I_{\beta}(L)}{\left(I_{\beta}(L)\right)_{\max }}\right] .
$$


The statistical relationships between features in (1) are taken into account in all of their pair combinations. The connections of higher orders were not taken into account because of their non-essentialness for practical calculations [33]. As can be seen from (1), in order to find the informativeness of the feature set, it is necessary to estimate the statistical relationships between them, which are characterized by the coefficient $\gamma_{k \beta}$. To do this we use the criterion, which are based on the measured frequencies differences of the consistent occurrence of the features discrete values with a hypothetical distribution of frequencies, which corresponds to the condition of the features independence.

First, assume that the features are statistically independent. The hypothetical frequency distribution, which corresponds to this condition, needs to be verified statistically. To do this, use the Pearson criterion.

Assume that it is necessary to quantify the statistical relationship between the features $x_{1}$ and $x_{2}$, which in general can have several values $x_{1 j}$ and $x_{2 \phi}(\phi=\overline{1, q}, q$ - maximum number of values for the feature $\phi$ ).

In Table 1 shows the distributions of the measured frequencies $M_{j \phi}$ of the compatible appearance of the $j$ value of the $x_{1}$ feature and the $\phi$ value of the $x_{2}$ feature.

$$
\begin{gathered}
\text { In this table }\left(M_{j}\left(x_{2 q}\right)=\sum_{\phi=1}^{q} M_{j \phi} \text { for } j=\text { const }\right) \text {; } \\
\left(M_{\phi}\left(x_{1 J}\right)=\sum_{j=1}^{J} M_{j \phi} \text { при } \phi=\text { const }\right) . \\
W=\sum_{j=1}^{J} M_{j}\left(x_{2 \phi}\right)=\sum_{\phi=1}^{q} M_{\phi}\left(x_{1 j}\right) . \\
\left\lfloor M_{j \phi}^{0}\right\rfloor=\left[M_{j}\left(x_{2 q}\right)\right]\left[M_{q}\left(x_{1 J}\right)\right] / W .
\end{gathered}
$$

From hypothetical frequencies $\left\lfloor M_{j \phi}^{0}\right\rfloor$ we can find

$$
v^{2}=\sum_{j=1}^{J} \sum_{\phi=1}^{q} \frac{\left(M_{j \phi}-\left[M_{j \phi}^{0}\right]^{2}\right)^{2}}{\left[M_{j \phi}^{0}\right]} .
$$

The double sum (2) is distributed approximately $\chi_{k \beta}^{2}$ with the number of degrees of freedom $\xi=(J-1)(q-1)$ [33]. Therefore, we will assume that $\chi_{k \beta}^{2}=v^{2}$.

The larger the value $\chi_{k \beta}^{2}$ for each pair of feature $x_{k}$ and $x_{\beta}$, the greater the statistical relationship between them (for a statistically independent pair of features $M_{j \phi}=\left\lfloor M_{j \phi}^{0}\right\rfloor$ and $\chi_{k \beta}^{2}=0$.

\begin{tabular}{|c|c|c|c|c|c|}
\hline \multirow{2}{*}{$X_{1}$} & \multicolumn{5}{|c|}{ Value $x_{2}$} \\
\hline & $x_{21}$ & $x_{22}$ & $\ldots$ & $x_{2 q}$ & $\sum$ \\
\hline \multirow[t]{2}{*}{$x_{11}$} & $\left\lfloor M_{11}^{0}\right\rfloor$ & $\left\lfloor M_{12}^{0}\right\rfloor$ & \multirow[b]{2}{*}{$\cdots$} & $M_{1 q}^{0}$ & \multirow{2}{*}{$M_{1}\left(x_{2 q}\right)$} \\
\hline & $M_{11}$ & $M_{12}$ & & $M_{1 q}$ & \\
\hline \multirow[t]{2}{*}{$x_{12}$} & $\left\lfloor M_{21}^{0}\right\rfloor$ & $\left\lfloor M_{22}^{0}\right\rfloor$ & \multirow[b]{2}{*}{$\cdots$} & {$\left[M_{2 q}^{0}\right]$} & \multirow{2}{*}{$M_{2}\left(x_{2 q}\right)$} \\
\hline & $M_{21}$ & $M_{22}$ & & $M_{2 q}$ & \\
\hline \multirow[b]{2}{*}{$\cdots$} & \multirow[b]{2}{*}{$\cdots$} & \multirow[b]{2}{*}{$\cdots$} & {$\left[M_{j \phi}^{0}\right]$} & \multirow[b]{2}{*}{$\cdots$} & \multirow[b]{2}{*}{$\cdots$} \\
\hline & & & $M_{j \phi}$ & & \\
\hline \multirow[t]{2}{*}{$x_{1 J}$} & $\left\lfloor M_{J 1}^{0}\right\rfloor$ & $\left\lfloor M_{J 2}^{0}\right\rfloor$ & \multirow[b]{2}{*}{$\cdots$} & {$\left[M_{J q}^{0}\right]$} & \multirow[t]{2}{*}{$M_{J}\left(x_{2 q}\right)$} \\
\hline & $M_{J 1}$ & $M_{J 2}$ & & $M_{J q}$ & \\
\hline$\sum$ & $M_{1}\left(x_{1 J}\right)$ & $M_{2}\left(x_{1 J}\right)$ & & $M_{q}\left(x_{1 J}\right)$ & $W$ \\
\hline
\end{tabular}

(C) Humeniuk M. O., Sashchuk I. M., Zhuravsky Yu. V., 2018 DOI 10.15588/1607-3274-2018-4-9
Table 1 - Frequencies of compatible appearance of the $j$ value of the $x_{1}$ feature and the $\phi$ value of the $x_{2}$ feature

When using Pearson's criterion in expression (1), the value $\chi_{k \beta}^{2}$ for the pairs of features should be normalized by dividing them by $\left(\chi_{k \beta}^{2}\right)_{\max }$ for this pair of features, that is, one has to find $\gamma_{k \beta}=\chi_{k \beta}^{2} /\left(\chi_{k \beta}^{2}\right)_{\max }$ where $\left(\chi_{k \beta}^{2}\right)_{\max }=W$.

However, the value of the mutual information depends on the number of the investigated system states. However, when conducting robots measurements we can have different number of the explored environment state. Therefore, in practical calculations of informative it is expedient to use the relative mutual information received by the multi robots team, whose value does not depend on the number of the environment states.

We can find it as $E(L)=\frac{I(L)}{H_{0}(L)}$.

The required amount of mutual information of the environment state $I_{r}(L)$ to provide the required classification error $p_{e}^{r}(L)$ is defined as $I_{r}(L)=H_{0}(L)-H_{r}(L)$, where $H_{r}(L)$ is the required entropy of the environment state $L$.

To provide the required value of the feature set informativeness for multi robot teams control the condition

$$
p_{e}(L) \leq p_{e}^{r}(L)
$$

have to be met.

However, as noted in [32], there is no functional relationship between conditional entropy and classification error.

Therefore, the condition $I(L) \geq I_{r}(L)$ is necessary, but not sufficient to ensure the necessary probability of making a false decision about the state of environment. 
So, if a decision is taken on one of the two states of the system, in order to unambiguously guarantee the necessary value of the average probability of making a false decision, it is enough to fulfill the condition $I(L)-\mathrm{I}_{r}(L) \geq I^{*}$ or

$$
\mathrm{H}_{r}(L)-H(L / x) \geq I^{*},
$$

where

$$
\begin{aligned}
& I^{*}=-H(L / x)\left(1+0,5 \log _{2} 0,5 H(L / x)\right)- \\
& -(1-0,5 H(L / x)) \log _{2}(1-0,5 H(L / x))
\end{aligned}
$$

to ensure compliance with the condition (3).

We prove the sufficiency of the condition (4), for this we use the well-known expressions for the exact upper and lower bounds of the mean condition entropy $H(L / x)$ at a given average probability of error $p_{e}(L)$. These expressions in accordance with the theorem of Kovalevsky [32] is presented in this form

$$
\begin{gathered}
\sup H(L / x)=-p_{e}(L) \log _{2} p_{e}(L)-\left(1-p_{e}(L)\right) \log _{2}\left(1-p_{e}(L)\right), \\
\inf H(L / x)=2 p_{e}(L) .
\end{gathered}
$$

On the basis of expression (7), we conclude that for a given average conditional entropy $H(L / x)$, for the average probability of recognition error $p_{e}(L)$, inequality holds true

$$
p_{e}(L) \leq 0,5 H(L / x) \text {. }
$$

Inequality (8) is correct, since assuming the opposite; we find that $H(L / x)<2 p_{e}(L)$ this contradicts the condition (7).

We will proceed from the fact that the condition (4) is fulfilled, then, taking into account (5), we obtain

$$
\begin{aligned}
& H_{r}(L)<-0,5 H(L / x) \log _{2} 0,5 H(L / x)- \\
& -(1-0,5 H(L / x)) \log _{2}(1-0,5 H(L / x))
\end{aligned}
$$

Under this condition

$$
p_{e}^{r}(L)<0,5 H(L / x)
$$

Indeed, let's assume the opposite, that is $p_{e}^{r}(L) \geq 0,5 H(L / X)$. With this assumption, taking into account that $H(L / x) \leq 1$, and $\sup H(L / x)$ according to (5) is monotonically increasing function from $p_{e}(L)$ when $p_{e}(L) \leq 0,5$, we obtain

$$
\begin{aligned}
& H_{r}(L) \geq-0,5 H(L / x) \log _{2} 0,5 H(L / x)- \\
& -(1-0,5 H(L / x)) \log _{2}(1-0,5 H(L / x)) .
\end{aligned}
$$

(C) Humeniuk M. O., Sashchuk I. M., Zhuravsky Yu. V., 2018 DOI 10.15588/1607-3274-2018-4-9
However, this inequality contradicts (9). Thus, inequality is confirmed (10). Comparison (8) and (10) allow us to conclude that when the condition (4) is fullfilled so (3) is also fullfilled.

Thus, ensuring the required value of the entropy solution is a necessary, but not sufficient condition for the decision on the state of the environment with the required probability. In order to ensure a condition $p_{e}(L) \geq p_{e}^{r}(L)$, it is sufficient that the condition (3) is fulfilled.

However, the sufficiency of the condition (3) can be satisfied not only by the fulfillment of conditions (4), but also the fulfillment of the condition

$$
\mathrm{H}_{r}(L)-\mathrm{H}(L / x) \geq I_{r}^{*} .
$$

Thus, knowing the lower boundary of the required conditional entropy $H_{r}(L / x)$ at the given required probability of classification error $p_{e}^{r}$, the value $I_{r}^{*}$ should be defined as the difference between the required entropy $H_{r}(L)$ and inf $H_{r}(L / x)$ by the expression

$$
I_{r}^{*}=H_{r}(L)-\inf H_{r}(L / x),
$$

where

$$
\inf H_{r}(L / x)=2 p_{e}^{r}
$$

Substituting the expressions (13) into expression (12) we obtain:

$$
I_{r}^{*}=-p_{e}^{r} \log _{2} p_{e}^{r}-\left(1-p_{e}^{r}\right) \log _{2}\left(1-p_{e}^{r}\right)-2 p_{e}^{r} .
$$

Let us prove the condition (11). On the basis of expression (14), the condition (11) can be represented as $H_{r}(L)-H(L / x) \geq H_{r}(L)-2 p_{e}^{r}$. Or

$$
H(L / x)<2 p_{e}^{r} .
$$

We will show that under this condition $p_{e}<p_{e}^{r}$. Yes, in fact, assuming the opposite, that is, that $p_{e} \geq p_{e}^{r}$ on the basis of expression (7) we obtain inf $H(L / x) \geq 2 p_{e}^{r}$.

However, this condition contradicts the condition (15). Consequently, the sufficiency of the condition (11) is proved.

The value of the lower bound of the required conditional entropy in accordance with [32] can be found taking into account the a priori probabilities of in terms of expression

$$
\inf H_{r}(L / x)=-p_{0} \log _{2}\left(\frac{p_{0}}{p_{0}+p_{e}^{r}}\right)-p_{e}^{r} \log _{2}\left(\frac{p_{e}^{r}}{p_{0}+p_{e}^{r}}\right) .
$$

Where $p_{0}=\min \left\{p\left(L_{1}\right), p\left(L_{2}\right)\right\}$. 
Therefore, in accordance with (12), and taking into account (16), the value $I_{r}^{*}$ can be determined by expression

$$
\begin{aligned}
& I_{r}^{*}=-p_{e}^{r} \log _{2} p_{e}^{r}-\left(1-p_{e}^{r}\right) \log _{2}\left(1-p_{e}^{r}\right)+ \\
& +p_{0} \log _{2}\left(\frac{p_{0}}{p_{0}+p_{e}^{r}}\right)+p_{e}^{r} \log _{2}\left(\frac{p_{e}^{r}}{p_{0}+p_{e}^{r}}\right) .
\end{aligned}
$$

\section{EXPERIMENTS}

Distribution of the entropy $H(L / x)$, depending on classification error $p_{e}$, is presented in the Fig. 1.

Distribution of mutual information $I_{r}^{*}$, depending on the entropy $H(L / X)$, is presented in the Fig. 2.

Distribution of $I_{r}^{*}$, depending on $p_{e}^{r}$ with condition $p_{0}=$ const, is presented in the Fig. 3 .

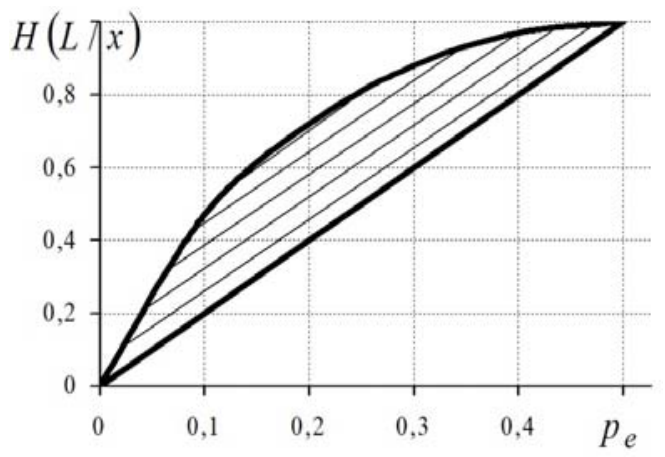

Figure 1 - Graph of dependence between $H(L / x)$ and $p_{e}$

Numerical study of the developed software system application based on the proposed estimation criterion and the traditional methods of effectiveness estimation shows that proposed criterion in average by $5 \%$ reduces the informativeness of the feature set.

For example in Tables $2-4$ are presented probabilities of the situation when a features has different values on condition that output parameters has values $L_{1}$ and $L_{2}$.

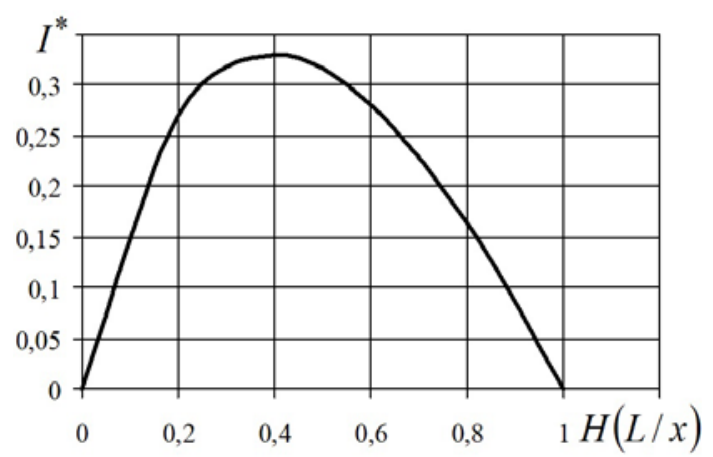

Figure 2 - Graph of dependence between $I_{r}^{*}$ and $p_{e}^{r}$

(C) Humeniuk M. O., Sashchuk I. M., Zhuravsky Yu. V., 2018 DOI 10.15588/1607-3274-2018-4-9

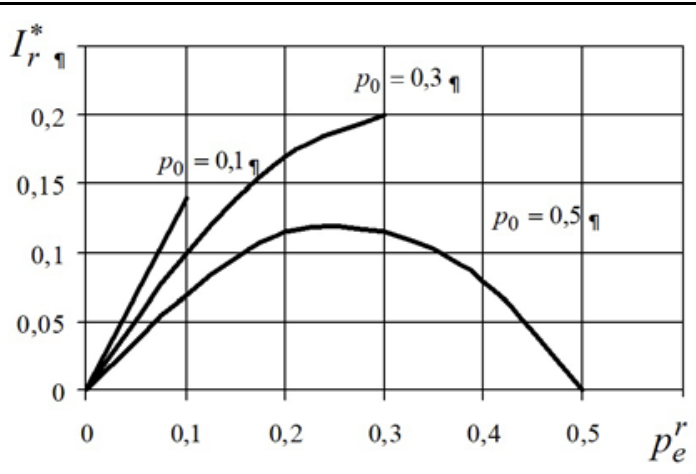

Figure 3 - Graph of dependence between $I_{r}^{*}$ and $p_{e}^{r}$ if

$$
p_{0}=\text { const }
$$

Table 2 - Probabilities $p\left(x_{1} / L_{i}\right)$ of the feature $x_{1}$

\begin{tabular}{|c|c|c|c|}
\hline state $L_{i}$ & $x_{11}$ & $x_{12}$ & $x_{13}$ \\
\hline$L_{1}$ & 0,1 & 0,8 & 0,1 \\
\hline$L_{2}$ & 0,5 & 0,1 & 0,4 \\
\hline
\end{tabular}

Table 3 - Probabilities $p\left(x_{2} / L_{i}\right)$ of the feature $x_{2}$

\begin{tabular}{|c|c|c|c|}
\hline state $L_{i}$ & $x_{11}$ & $x_{12}$ & $x_{13}$ \\
\hline$L_{1}$ & 0,1 & 0,8 & 0,1 \\
\hline$L_{2}$ & 0,5 & 0,1 & 0,4 \\
\hline
\end{tabular}

Table 4 - Probabilities $p\left(x_{3} / L_{i}\right)$ of the feature $x_{3}$

\begin{tabular}{|c|c|c|c|}
\hline state $L_{i}$ & $x_{11}$ & $x_{12}$ & $x_{13}$ \\
\hline$L_{1}$ & 0,1 & 0,8 & 0,1 \\
\hline$L_{2}$ & 0,5 & 0,1 & 0,4 \\
\hline
\end{tabular}

Further, in accordance with our approach we determine the values of the informativeness of each feature. As a result of calculations we obtain the values $E_{k}$ that are presented in the Table 5.

Table 5 - The obtained values of the feature relative informativeness

\begin{tabular}{|c|c|c|}
\hline$E_{1}$ & $E_{2}$ & $E_{3}$ \\
\hline 0,40 & 0,10 & 0,15 \\
\hline
\end{tabular}

On the basis of the obtained values of the feature relative informativeness we determine the relative informativeness of the feature set. Since the ignoring of the statistical relationships between the features overestimates the relative informativeness of the feature set, it leads to an incorrect definition of its informativeness of the feature set. Therefore, we will determine the relative informativeness of the feature set, taking into account the statistical relationships between the features. To do this 
we will determine the value of the statistical coupling coefficients for each pair of signs $\gamma_{k \beta}$.

Further, we determine the relative informativeness of the feature set, taking into account the statistical relationships between the features $E(L)=0.62$. Excluding $E(L)=0.65$.

From the obtained results it is clear that the inclusion of statistical links between features by $5 \%$ reduces the informativeness of the feature set, which leads to a more accurate determination of the possible efficiency indicator.

\section{DISCUSSION}

As can be seen from the data shown in the Figure 1, there is an ambiguous relationship between the probability of classification error $p_{e}$ and the entropy of the decision $H(L / x)$. Thus, ensuring the required value of the entropy solution is a necessary, but not sufficient condition for the decision on the state of the environment with the required probability. In order to ensure a condition $p_{e}(L) \geq p_{e}^{r}(L)$, it is sufficient that the condition (3).

From the analysis of the data shown in the Figure 2 and 3 , it is evident that, with a constant value of the required probability of classification error $p_{e}^{r}=$ const, the value $I_{r}^{*}$ determined by the expression (17) is less than that determined by the expression (5). Therefore, in order to determine the sufficient condition for the feature set informativeness when recognizing the environment state, it is expedient to use value $I_{r}^{*}$, which is determined by expression (5). Since this will provide the required probability of error to recognize the environment state. It provides control of the multi robot teams which minimize the ratio of incorrectly recognized measurements to the total number of measurements.

Thus the proposed criterion for feature set informativeness estimation in the task of multi robot teams control allows to efficiently solve the problem of feature set informativeness estimation, leading to effective solution of the multi robots control task. At that in comparison with traditional feature set informativeness estimation approaches based on the maximizing mutual information criterion this process is applicable when measurements are interdepended, environment has a variable number of states and allow estimate the ratio of incorrectly recognized measurements to the total number of measurements.

\section{CONCLUSIONS}

In this paper the actual task of automation of feature set informativeness estimation process in the task of multi robot teams control was solved.

The scientific novelty of obtained results is that the method of feature set informativeness estimation is improved. The improved method enables to estimate feature set informativeness in classification problems in situations when input data samples contain interdependent features and environment has a variable number of states. The proposed criterion is based on the idea that feature set significance is computed according to the mutual information of the multi robot teams next observation. The article defines a sufficient condition for ensuring the require probability of making a false decision on the environment state and proves it. The fulfillment of this condition guarantees a decision on the environment state with the required probability.

Application of the proposed criterion of features set informativeness estimation allows us to make a decision how much a new observation will increase the certainty of the robots' beliefs about the environment state. Practical significance of the paper consists in the solution of practical problems of multi robot teams control. Experimental results showed that the proposed criterion allowed to estimate feature set informativeness and it could be used in practice for solving of practical tasks of multi robot teams control.

\section{ACKNOWLEDGEMENTS}

The work was performed as part of the scientific research work № 4K13 "The information theoretic approach to multi robot teams control" at the department of unmanned aircraft systems applications of Zhytomyr Military Institute named after S.P.Koroliov by support of the department staff.

\section{REFERENCES}

1. Charrow B. Information-theoretic active perception for multi-robot teams, $\mathrm{PhD}$ thesis. Phi-ladelphia, University of Pennsylvania, 2015, $175 \mathrm{p}$.

2. Oliinyk A. A. Subbotin S. A., Lovkin V. M. et al. The system of criteria for feature informativeness estimation in pattern recognition, Radio Electronics Computer Science Control, 2017, No. 4, pp. 85-96. DOI 10.15588/1607-32742017-4-10.

3. McLachlan G. Discriminant Analysis and Statistical Pattern Recognition. New Jersey, John Wiley \& Sons, 2004, 526 p. DOI: $10.1002 / 0471725293$.

4. Hyvarinen A., Karhunen J., Oja E. Independent component analysis. New York, John Wiley \& Sons, 2001, 481 p. DOI: $10.1002 / 0471221317$

5. Grocholsky B. Information-theoretic control of multiple sensor platforms, PhD thesis. Sydney, University of Sydney, 2002, 199 p.

6. Grocholsky B., Makarenko A., Durrant-Whyte H. Information theoretic control of multiple sensor platforms, Proceedings of the IEEE International Conference on Robotics and Automation, 2003, Vol. 1, pp. 1521-1526.

7. Bourgault F., Makarenko A., Williams S. B. Information based adaptive robotic exploration, Proceedings of the IEEE International Conference on Intelligent Robots and Systems, 2002, pp. 540-545.

8. Choi H. L., How J. P. Continuous trajectory planning of mobile sensors for informative forecasting. Automatica, 2011, 145 p.

9. Ny J. L., Pappas G. J. On trajectory optimization for active sensing in gaussian process models, Proceedings of the Joint IEEE Conference on Decision and Control and Chinese Control Conference, 2009, pp. 6282-6292. 
10. Singh A., Krause A., Guestrin C. Efficient planning of informative paths for mul-tiple robots, Proceedings of the International Joint Conference on Artificial Intelligence, 2007, pp. 93-105.

11. Hoffmann G. M., Tomlin C. J. Mobile sensor network control using mutual information methods and particle filters, IEEE Transactions on Automatic Control, 2010, Vol. 55(1), pp. 32-47.

12. Julian B. J., Angermann M., Schwager M. et al. A scalable information theoretic approach to distributed robot coordination, IEEE/RSJ Conference on Intelligent Robots and Systems (IROS), 2011, pp. 46-53.

13. Philip D. Schwager M., Kumar V. et al. A Decentralized Control Policy for Adaptive Information Gathering in Hazardous Environments, 2012 IEEE 51st IEEE Conference on Decision and Control, 2012, pp. 74-86.

14. Zhao F., Shin J., Reich J. Information-driven dynamic sensor collaboration, IEEE Signal Processing Magazine, 2002, pp. 61-72.

15. Leonard N. E., Paley D. A., Lekien F. et al. Collective motion, sensor networks, and ocean sampling, Processing IEEE, 2007, Vol. 95, No. 1, pp. 48-74.

16. Feng X., Loparo K. A., Fang Y. Optimal state estimation for stochastic systems: An information theoretic approach, IEEE Transactions on Automatic Control, 1997, Vol. 42, No. 6, pp. 771-785.

17. Kreucher C., Kastella K., Hero A. O. Information based sensor management for multitarget tracking, Processing SPIE, Bellingham, WA, 2003, Vol. 5204, pp. 480-489.

18. Tisdale J., Ryan A., Kim Z. et al. A multiple uav system for vision-based search and localization, Processing $A A C C$ American Control Conference, Seattle, WA, 2008, pp. 1985 1990.

19. Ryan A. Information-theoretic tracking control based on particle filter estimate, Processing AIAA Guidance, Navigation, Control Conference, Honolulu, HI, Aug., 2008, pp. 346-358.

20. Williams J. L. Information Theoretic Sensor Management, PhD dissertation. MITEE, Cambridge, MA, 2007, $181 \mathrm{p}$

21. Hoffmann G. M., Waslander S. L. and Tomlin C. J. Mutual information methods with particle filters for mobile sensor network control, Proceedings 45th IEEE Conference Decision Control, San Diego, CA, 2006, P. 1019-1024.
22. Krause A., Guestrin C. Near-optimal nonmyopic value of information in graphical models, In Uncertainty in AI, 2005, pp. 324-331.

23. Singh A., Krause A., Guestrin C. et al. Efficient informative sensing using multiple robots, Journal of AI Research, 2009, No. 34(1), pp. 707-755.

24. Binney J., Krause A., Sukhatme G. S. Optimizing waypoints for monitoring spatiotemporal phenomena, International Journal Robotics Research, 2013, No. 32(8), pp. 873-888.

25. Hollinger G., Sukhatme G. Sampling-based motion planning for robotic information gathering, In Proceedings of Robotics: Science and Systems, Berlin, Germany, 2013, pp. 207219.

26. Hollinger G. Englot B., Hover F. S. et al. Active planning for underwater inspection and the benefit of adaptivity, International Journal Robotics Research, 2003, No. 32(1), pp. 3-18.

27. Kretzschmar H., Stachniss C. Information-theoretic compression of pose graphs for laser-based slam, International Journal Robotics Research, 2012, № 31(11), pp. 1219 1230.

28. Dame A., Marchand E. Mutual Information-based Visual Servoing, IEEE Transactions on Robotics, 2011, No. 27(5), pp. 958-969.

29. Maddern W., Harrison A., Newman P. Lost in translation (and rotation): Rapid extrinsic calibration for $2 \mathrm{~d}$ and $3 \mathrm{~d}$ lidars, Processing of the IEEE International Conference on Robotics and Automation, 2012, pp. 3096-3102.

30. Whaite P., Ferrie F. P. Autonomous Exploration: Driven by Uncertainty, IEEE Transactions on Pattern Analysis and Machine Intelligence, 1997, No. 19(3), pp. 193-205.

31. Kretzschmar H., Stachniss C. Information-theoretic compression of pose graphs for laser-based slam, International Journal Robotics Research, 2012, No.31(11), pp. 1219 1230.

32. Fainzillberg L. S. Mathematical methods for evaluating the usefulness of diagnostic features: monograph. Kiev, "Osvita Ukrainu", 2010, P. 152.

33. Anisimov B. V., Kurganov V. D., Zlobin V. K. Recognition and digital image processing: study way for college student. Moscow, Vushchaya shkola, 1983, 295 p.

Received 25.09.2018 Accepted 16.10.2018.

УДК 004.93

\section{КРИТЕРІЙ ОЦІНЮВАННЯ ІНФОРМАТИВНОСТІ ОЗНАК ПРИ УПРАВЛІННІ ГРУПОЮ РОБОТІВ}

Гуменюк М. О. - канд. техн. наук, доцент кафедри застосування безпілотних авіаційних комплексів, Житомирський військовий інститут імені С. П. Корольова, Житомир, Україна.

Сащук І. М. - канд. техн. наук, старший науковий співробітник, заступник начальника інституту з навчальної та наукової роботи, Житомирський військовий інститут імені С. П. Корольова, Житомир, Україна.

Журавський Ю. В. - д-р техн. наук, старший науковий співробітник, провідний науковий співробітник наукового центру, Житомирський військовий інститут імені С. П. Корольова, Житомир, Україна.

\section{АНОТАЦЯ}

Актуальність. Вирішено задачу автоматизації процесу оцінювання інформативності ознак при управлінні групою роботів. Об'єкт дослідження - управління групою роботів. Предмет дослідження - критерій оцінювання інформативності ознак. Мета роботи полягає в розробці критерію оцінювання інформативності ознак при управлінні групою роботів.

Метод. Запропоновано критерій оцінювання інформативності ознак. Розроблений критерій передбачає визначення інформативності набору ознак на основі значень апріорних ймовірностей знаходження ознак в описах станів навколишнього середовища. Використання запропонованого критерію дозволяє ефективно вирішувати завдання щодо оцінювання інформативності ознак. Це надає змогу приймати ефективні рішення при управлінні групою роботів. Розроблений критерій базується на критерії максимальної кількості інформації та може бути застосований в ситуаціях, коли отриманні вимірювання не $\epsilon$ незалежними, а навколишнє середовище має змінну кількість станів. Запропонований критерій не вимагає побудови моделей на основі оцінюваних комбінацій ознак, що істотно знижує часові та обчислювальні витрати при управлінні групою 
роботів. Використання запропонованого критерію для оцінювання інформативності набору ознак дозволяє приймати рішення наскільки нове спостереження збільшить обізнаність роботів щодо стану досліджуваного навколишнього середовища.

Результати. Розроблено програмне забезпечення, що реалізує запропонований критерій оцінювання інформативності ознак та дозволяє управляти групою роботів.

Висновки. Проведені експерименти підтвердили працездатність запропонованого критерію оцінювання інформативності ознак і дозволяють рекомендувати його для використання на практиці при управління групою роботів. Перспективи подальших досліджень можуть полягати в модифікації існуючих і розробці нових методів управління групою роботів на основі запропонованого критерію оцінювання інформативності ознак.

КЛЮЧОВІ СЛОВА: управління групою роботів, взаємна інформація, критерій інформативності, інформативність групи ознак.

УДК 004.93

\section{КРИТЕРИЙ ОЦЕНКИ ИНФОРМАТИВНОСТИ ПРИЗНАКОВ ПРИ УПРАВЛЕНИИ ГРУППОЙ РОБОТОВ}

Гуменюк М. А. - канд. техн. наук, доцент кафедры использования беспилотных авиационных комплексов, Житомирский военный институт имени С. П. Корольова, Житомир, Украина.

Сащук И. М. - канд. техн. наук, старший научный сотрудник, заместитель начальника института с учебной и научной работы, Житомирский военный институт имени С. П. Корольова, Житомир, Украина.

Журавський Ю. В. - д-р техн. наук, старший научный сотрудник, ведущий научный сотрудник научного центра, Житомирский военный институт имени С. П. Корольова, Житомир, Украина.

\section{АННОТАЦИЯ}

Актуальность. Решена задача автоматизации процесса оценки информативности признаков управлении группой роботов. Объект исследования - управление группой роботов. Предмет исследования - критерий оценки информативности признаков. Цель работы заключается в разработке критерия оценки информативности признаков для группы роботов.

Метод. Предложен критерий оценки информативности признаков. Разработанный критерий предполагает определение информативности набора признаков на основе значений априорных вероятностей нахождения признаков в описаниях состояний окружающей среды. Использование предложенного критерия позволяет эффективно решать задачи по оценке информативности признаков. Это дает возможность принимать эффективные решения при управлении группой роботов. Разработанный критерий базируется на критерии максимального количества информации и может быть применен в ситуациях, когда получении измерения не являются независимыми, а окружающая среда имеет переменное количество состояний. Предложенный критерий не требует построения моделей на основе оцениваемых комбинаций признаков, существенно снижает временные и вычислительные затраты при управлении группой роботов. Использование предложенного критерия для оценки информативности набора признаков позволяет принимать решения насколько новое наблюдение увеличит осведомленность роботов по состоянию исследуемой окружающей среды.

Результаты. Разработано программное обеспечение, реализующее предложенный критерий оценки информативности признаков и позволяет управлять группой роботов.

Выводы. Проведенные эксперименты подтвердили работоспособность предложенного критерия оценки информативности признаков и позволяют рекомендовать его для использования на практике при управлении группой роботов. Перспективы дальнейших исследований могут заключаться в модификации существующих и разработке новых методов управления группой роботов на основе предложенного критерия оценки информативности признаков.

КЛЮЧЕВЫЕ СЛОВА: управление группой роботов, взаимная информация, критерий информативности, информативность группы признаков.

\section{ЛІТЕРАТУРА / ЛИТЕРАТУРА}

1. Charrow B. Information-theoretic active perception for multi-robot teams, PhD thesis / Benjamin Charrow. - Philadelphia: University of Pennsylvania, 2015. - $175 \mathrm{p}$.

2. The system of criteria for feature informativeness estimation in pattern recognition / [A. A. Oliinyk, S. A. Subbotin, V. M. Lovkin et al.] // Радіоелектроніка, інформатика, управління. - 2017. - № 4. - C. 85-96. DOI 10.15588/1607-3274-2017-4-10.

3. McLachlan G. Discriminant Analysis and Statistical Pattern Recognition / G. McLachlan. - New Jersey : John Wiley \& Sons. -2004 . -526 p. DOI: 10.1002/0471725293.

4. Hyvarinen A. Independent component analysis / A. Hyvarinen, J. Karhunen, E. Oja. - New York : John Wiley \& Sons, 2001. - 481 p. DOI: 10.1002/0471221317.

5. Grocholsky B. Information-theoretic control of multiple sensor platforms, PhD thesis / Grocholsky Ben. - Sydney: University of Sydney, 2002. - 199 p.

6. Grocholsky B. Information theoretic control of multiple sensor platforms. / B. Grocholsky, A. Makarenko, H. Dur-
rant-Whyte // Proceedings of the IEEE International Conference on Robotics and Automation. - 2003. - Vol. 1. P. 1521-1526.

7. Bourgault $F$. Information based adaptive robotic exploration / F. Bourgault, A. Makarenko, S. B. Williams // In Proceedings of the IEEE International Conference on Intelligent Robots and Systems. -2002 . - P. 540-545.

8. Choi H. L. Continuous trajectory planning of mobile sensors for informative forecasting / H. L. Choi, J. P. How // Automatica. - 2011. - $145 \mathrm{p}$.

9. Ny J. L. On trajectory optimization for active sensing in gaussian process models / J. L. Ny, G. J. Pappas // In Proceedings of the Joint IEEE Conference on Decision and Control and Chinese Control Conference. - 2009. P. 6282-6292.

10. Singh A. Efficient planning of informative paths for multiple robots / A. Singh, A. Krause, C. Guestrin // Proceedings of the International Joint Conference on Artificial Intelligence. -2007 . - P. 93-105. 
11. Hoffmann G. M. Mobile sensor network control using mutual information methods and particle filters / G. M. Hoffmann, C. J. Tomlin // IEEE Transactions on Automatic Control. - 2010. - Vol. 55(1). - P. 32-47.

12. A scalable information theoretic approach to distributed robot coordination / [B. J. Julian, M. Angermann, M. Schwager et al.] // IEEE/RSJ Conference on Intelligent Robots and Systems (IROS). - 2011. - P. 46-53.

13. Philip D. A Decentralized Control Policy for Adaptive Information Gathering in Hazardous Environments / [D. Philip, M. Schwager, V. Kumar et al.] // 2012 IEEE 51st IEEE Conference on Decision and Control. - 2012. - P. 7486.

14. Zhao F. Information-driven dynamic sensor collaboration / F. Zhao, J. Shin, J. Reich // IEEE Signal Processing Magazine. -2002 . - P. 61-72.

15. Collective motion, sensor networks, and ocean sampling / [N. E. Leonard, D. A. Paley, F. Lekien et al.] // Processing IEEE. - 2007. - Vol. 95, № 1. - P. 48-74.

16. Feng X. Optimal state estimation for stochastic systems: An information theoretic approach / X. Feng, K. A. Loparo, Y. Fang // IEEE Transactions on Automatic Control. 1997. - Vol. 42, № 6. - P. 771-785.

17. Kreucher C. Information based sensor management for multitarget tracking / C. Kreucher, K. Kastella, A. O. Hero // Processing SPIE, Bellingham, WA. - 2003. - Vol. 5204. P. 480-489.

18. A multiple uav system for vision-based search and localization / [J. Tisdale, A. Ryan, Z. Kim et al.] // Processing AACC American Control Conference, Seattle, WA. 2008. - P. 1985-1990.

19. Ryan A. Information-theoretic tracking control based on particle filter estimate / A. Ryan // Processing AIAA Guidance, Navigation, Control Conference, Honolulu, HI, Aug. 2008. - P. 346-358.

20. Williams J. L. Information Theoretic Sensor Management, Ph.D. dissertation / J. L. Williams. - MITEE, Cambridge, MA, 2007. - $181 \mathrm{p}$.

21. Hoffmann G. M. Mutual information methods with particle filters for mobile sensor network control / G. M. Hoffmann, S. L. Waslander, and C. J. Tomlin // Proceedings 45th IEEE Conference Decision Control, San Diego, CA. - 2006.P. 1019-1024.

22. Krause A. Near-optimal nonmyopic value of information in graphical models / A. Krause, C. Guestrin // In Uncertainty in AI. - 2005. - P. 324-331.
23. Singh A. Efficient informative sensing using multiple robots / [A. Singh, A. Krause, C. Guestrin et al.] // Journal of AI Research. - 2009. - № 34(1). - P. 707-755.

24. Binney J. Optimizing waypoints for monitoring spatiotemporal phenomena / J. Binney, A. Krause, G. S. Sukhatme // International Journal Robotics Research. - 2013. № 32(8). - P. 873-888.

25. Hollinger G. Sampling-based motion planning for robotic information gathering / G. Hollinger, G. Sukhatme // In Proceedings of Robotics: Science and Systems. - Berlin, Germany. - 2013. - P. 207-219.

26. Active planning for underwater inspection and the benefit of adaptivity / [G. Hollinger, B. Englot, F. S. Hover et al.] // International Journal Robotics Research. - 2003. - № 32 (1). P. 3-18.

27. Kretzschmar H. Information-theoretic compression of pose graphs for laser-based slam / H. Kretzschmar, C. Stachniss // International Journal Robotics Research. - 2012. № 31(11). - P. 1219-1230.

28. Dame A. Mutual Information-based Visual Servoing / A. Dame, E. Marchand // IEEE Transactions on Robotics. 2011. -№ 27(5). - P. 958-969.

29. Maddern W. Lost in translation (and rotation): Rapid extrinsic calibration for $2 \mathrm{~d}$ and $3 \mathrm{~d}$ lidars / W. Maddern, A. Harrison, P. Newman // Processing of the IEEE International Conference on Robotics and Automation. - 2012 - P. 30963102.

30. Whaite P. Autonomous Exploration: Driven by Uncertainty / P. Whaite, F. P. Ferrie // IEEE Transactions on Pattern Analysis and Machine Intelligence. - 1997. - № 19(3). P. 193-205.

31. Kretzschmar H. Information-theoretic compression of pose graphs for laser-based slam / H. Kretzschmar, C. Stachniss // International Journal Robotics Research. - 2012. № 31(11). - P. 1219-1230.

32. Файнзильберг Л. С. Математические методы оценки полезности диагностических признаков : монография / Л. С. Файнзильберг. - К. : «Освита Украины», 2010. $152 \mathrm{c}$.

33. Анисимов Б. В. Распознавание и цифровая обработка изображений : учеб. пособ. для студентов вузов / Б. В. Анисимов, В. Д. Курганов, В. К. Злобин. - М. : Высшая школа, 1983. -295 с. 